\title{
Is Christian Zionism a heresy?
}

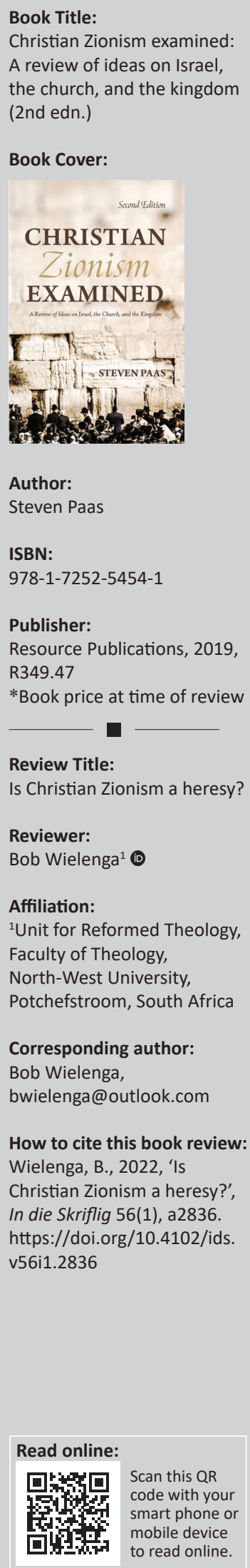

In 1948, after the dehumanising treatment of Jews in the German concentration camps during World War II, the Zionist movement, established by Theodor Herzl in 1897 in Basel, reached its main goal: the establishment of the Israeli state in their own homeland in Palestine. From that momentous event onward, Israel has not been out of the spotlight. The ongoing struggle between Jews and Palestinians, settled as inhabitants of the land during the Jewish diaspora, contributed to the ongoing political instability of the Middle East. But its formation also created divisions among Christians and their churches in the Western world. These divisions were mainly about the question of whether post-biblical Israel still must be regarded as the people of God, who in 1948 finally fulfilled the restoration prophecies of the Old Testament. And if so, which role then, has Israel as people, land, and religion to play in the history and order of salvation in the eschatological future? And what consequences does the answer have for the mission of the church? Should a dialogue with Israel be the calling of the church, based upon what they share, namely the Hebrew Bible or Old Testament? Or must Israel be approached like any other nation, as part of the worldwide mission of the church?

About these questions, and many more, Steven Paas, a Dutch missiologist and Church historian, who also served as a missionary in Malawi, wrote an informative book. He focuses on one dominant school of thinking, known as Christian Zionism. It is one stream of thinking in a much broader movement, labelled by him as Israelism. This is a multifaceted phenomenon dealing with all sorts of ethnic and political problems around the land and people of Israel in Palestine. In Christian Zionism, the focus is on the people, the land and the religion of Israel in the context of the history and order of salvation, as outlined in the Old and New Testament.

Paas describes in several chapters the development of Christian Zionism throughout history, from the Early Church onwards. It is not a recent phenomenon, born out of the holocaust, or earlier out of the Zionist movement started by Herzl in 1897. From biblical times onward, the church has been dealing with the status of Israel in God's salvation plan, after their rejection of their Messiah, Jesus Christ. A strong anti-Israel sentiment has always been present in the history of the church, that got its theological formulation in the replacement theology: the church has taken the place of Israel as God's people in all respects; there is no other calling for Israel than to repent and accept Christ just like any other nation. Paas points out that this replacement theology has contributed to the condemnation of the Jews, which led to the pogroms in Eastern Europe and finally to the holocaust. Paas rejects this whole approach and its praxis as non-Christian, conflicting with the biblical teachings.

But Paas rejects the opposite sentiment as well. A strong positive approach of Israel got a foothold in the Western church from the time of the Reformation onward, especially among Pietists and Puritans, among whom a postmillennial eschatology also found support. God would give Israel, converted to the Christian faith en masse, and returned to their own land, a new role to play in salvation history, initiating a worldwide missionary movement before the Parousia. This view became radicalised in the 19th to 20th century after the holocaust, to a premillennialist position on post-biblical Israel, supported by dispensationalism. A literalistic reading of the restoration prophecies plays a crucial part here. Another point of critique of Paas, is that here the Old Testament is not Christocentric read through the lenses of the New Testament, thereby minimising the contrast with the Jewish reading of the Hebrew Bible through the lenses of Mishna and Talmud. This also leads to a flawed view of covenant. For Paas, the universal covenant of grace, aiming at the inclusion of all believers, Jews and Gentiles together, is the unifying doctrine in canonical Scripture. The remnant of Christ confessing Jews represents all Israel, and forms together with the believing Gentiles the true people of God, as explained in Romans 9-11. In Appendix 1, Paas includes an excellent article of Bram Maljaars about Romans 11:26 ('and so all Israel will be saved').

Copyright: (C) 2022. The Authors. Licensee: AOSIS. This work is licensed under the Creative Commons Attribution License. 
In conclusion, this is a reliable introduction in a field of study that continues to provoke intense debate in Western Christianity. In South Africa too, there are signs of a growing interest in the pro-Israel ideology of Christian Zionism (Mogoeng Mogoeng). But in Paas' opinion, Christian Zionism in both its formats is a heresy. To counter it, he ends with some recommendations (chapter 10): change hermeneutics; drop Zionist millennialism; normalise attitudes towards Jews and Israel; be mission minded. In summary, this is also a useful study in the theological and ecclesiastical context of South Africa. 